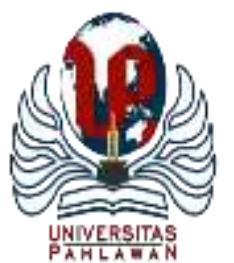

Edukatif : Jurnal Ilmu Pendidikan Volume 4 Nomor 1 Tahun 2022 Halm 217 - 226 EDUKATIF: JURNAL ILMU PENDIDIKAN

Research \& Learning in Education

https://edukatif.org/index.php/edukatif/index

\title{
Pengaruh Model Pembelajaran Kooperatif Tipe Snowball Throwing Berbantuan Media Video Terhadap Hasil Belajar Kognitif Siswa Sekolah Dasar
}

\author{
Islamiati Safitri $^{1 凶}$, Karimah $^{2}$, Emi Sulistri $^{3}$, Dina Anika Marhayani ${ }^{4}$ \\ Departemen Pendidikan Guru Sekolah Dasar, STKIP Singkawang, Kalimantan Barat, Indonesia ${ }^{1,2,3,4}$ \\ E-mail : islamiatisftri13@gmail.com ${ }^{1}$, karimahmiftahul252@ @mail.com $^{2}$, sulistriemi@ gmail.com $^{3}$, \\ dinaanika89@gmail.com ${ }^{4}$
}

\begin{abstract}
Abstrak
Penelitian ini bertujuan untuk mengetahui pengaruh penggunaan model pembelajaran Kooperatif Tipe Snowball Throwing Berbantuan Media Video terhadap hasil belajar kognitif siswa pada pembelajaran IPA. Jenis penelitian ini yaitu penelitian kuantitatif dengan metode quasi eksperimen design, dengan bentuk desain Nonequivalent Control Group Design. Populasi dalam penelitian ini adalah seluruh siswa kelas IV SDN 7 Singkawang. Sampel diambil menggunakan teknik sampling jenuh, sampel yang terpilih menjadi kelas eksperimen kelas IV A yaitu kelas eksperimen yang menggunakan model pembelajaran Kooperatif Tipe Snowball Throwing Berbantuan Media video dan kelas IV B kelas kontrol yang menggunakan model pembelajaran langsung. Hasil penelitian menyimpulkan bahwa : (1) Terdapat pengaruh model pembelajaran Kooperatif Tipe Snowball Throwing Berbantuan Media Video dengan hasil $t_{\text {hitung }}>\mathrm{t}_{\text {tabel }}=2.131033852>$ 2.00665. (2) Terdapat perbedaan hasil belajar kognitif siswa antara kelas yang diberikan model pembelajaran Kooperatif Tipe Snowball Throwing berbantuan media Video di kelas IV SDN 7 Singkawang. (3) Respon siswa positif terhadap model pembelajaran Kooperatif Tipe Snowball Throwing berbantuan media video termasuk dalam kriteria baik. Dengan demikian dapat disimpulkan bahwa penggunaan model kooperatif tipe snowball throwing berbantuan media video memberikan kesan menyenangkan, menarik perhatian, dan memberikan suasana yang baru.
\end{abstract}

Kata Kunci: Model Pembelajaran Kooperatif; Snowball Throwing; Hasil Belajar Kognitif

\begin{abstract}
This study aims to determine the effect of using the Snowball Throwing Type Cooperative learning model with the help of Video Media on students' cognitive learning outcomes in science learning. This type of research is quantitative research with a quasi-experimental design method, with the form of a Nonequivalent Control Group Design. The population in this study were all fourth grade students at SDN 7 Singkawang. The sample was taken using a saturated sampling technique, the sample was selected to be the experimental class, class IV A, namely the experimental class that used the cooperative learning model of Snowball Throwing Assisted by video media and class IV B, the control class that used the direct learning model. The results of the study concluded that: (1) There was an effect of the Snowball Throwing Type Cooperative Learning Model Assisted by Video Media with the results of tcount $>$ ttable $=2.131033852>2.00665$. (2) There are differences in students' cognitive learning outcomes between classes given the Snowball Throwing Type Cooperative learning model with the aid of Video media in class IV SDN 7 Singkawang. (3) Positive student responses to the Snowball Throwing Type Cooperative learning model assisted by video media are included in good criteria. Thus, it can be concluded that the use of a snowball throwing cooperative model with the help of video media gives a pleasant impression, attracts attention, and provides a new atmosphere.
\end{abstract}

Keywords: Cooperative Learning Model; Snowball Throwing; Cognitive Learning Outcomes.

Copyright (c) 2022 Islamiati Safitri,Karimah, Emi Sulistri, Dina Anika Marhayani

$\triangle$ Corresponding author

Email : islamiatisftri13@gmail.com

DOI : https://doi.org/10.31004/edukatif.v4i1.1667

ISSN 2656-8063 (Media Cetak)

ISSN 2656-8071 (Media Online)

Edukatif : Jurnal Ilmu Pendidikan Vol 4 No 1 Tahun 2022 p-ISSN 2656-8063 e-ISSN 2656-8071 
218 Pengaruh Model Pembelajaran Kooperatif Tipe Snowball Throwing Berbantuan Media Video Terhadap Hasil Belajar Kognitif Siswa Sekolah Dasar - Islamiati Safitri,Karimah, Emi Sulistri, Dina Anika Marhayani

DOI: https://doi.org/10.31004/edukatif.v4i1.1667

\section{PENDAHULUAN}

Ilmu Pengetahuan Alam (IPA) merupakan ilmu yang berkaitan dengan alam dan lingkungan sekitar. Menurut (Sari, 2012), IPA merupakan pengetahuan yang diperoleh melalui pengumpulan data dengan eksperimen, pengamatan, dan deduksi untuk menghasilkan suatu penjelasan tentang sebuah gejala yang dapat dipercaya. Kenyataan menunjukkan siswa akan belajar lebih bermakna jika anak mengalami apa yang dipelajarinya. Supaya siswa mampu menjelaskan dan mengaplikasikan konsep IPA, mereka harus mempelajari IPA sebagai produk, proses, dan bersikap ilmiah. Sesuai dengan tujuan pembelajaran IPA di SD tidak menjadikan siswa sebagai ahli bidang IPA, tetapi dimaksudkan agar siswa dimasukkan dalam ranah pemahaman anak didik, sebagai kemampuan untuk: (1) Mengingat dan mengulang konsep, prinsip, dan prosedur,(2) Mengidentifikasi dan memilih konsep, prinsip, dan prosedur, dan (3) Menerapkan konsep, prinsip, dan prosedur (Agustiana, 2009).

Pentingnya pembelajaran IPA di SD menjadikan siswa untuk berpikir secara positif yang memberikan dampak baik sehingga siswa menjadi tahu tentang teknologi dan ramah lingkungan sebagai elaborasi dari membaca IPA (Mariana, 2009). Menurut Iskandar (Iskandar, 1997), Pembelajaran IPA di SD dapat memberikan kesempatan untuk memupuk rasa ingin tahu siswa secara alamiah, hal ini akan membantu siswa mengembangkan kemampuan bertanya dan mencari jawaban berdasarkan bukti serta mengembangkan cara berpikir imiah.

Berdasarkan hasil prariset yang dilakukan di SDN 7 Singkawang, di temukan bahwa hasil belajar masih tergolong rendah. Hal tersebut dapat dilihat dari data awal yang diketahui hasil nilai ujian tengah semester (UTS) pembelajaran IPA di kelas IV SDN menunjukkan bahwa yang mendapatkan dibawah Kriteria Ketuntasan Minimal (KKM) ada 17 siswa, dan hanya 10 siswa yang memenuhi KKM. Data hasil nilai ujian tengah semester (UTS) siswa ditunjukkan dengan nilai terendah 40 dan nilai tertinggi 70 . Dari data yang diperoleh, maka dapat disimpulkan bahwa pembelajaran IPA pada kelas IV SDN perlu ditingkatkan lagi kualitas proses pembelajarannya, sehingga dapat meningkatkan hasil belajar siswa. Berbagai faktor yang juga mempengaruhi hasil belajar rendah, karena kurang tertariknya siswa dalam pembelajaran IPA, serta kurang bervariasi dalam pemilihan model dan media yang digunakan oleh guru sehingga siswa kurang semangat dalam proses pembelajaran.

Sesuai dengan hasil wawancara dengan guru di kelas IV SDN 7, bahwa beliau mengatakan dalam proses pembelajaran masih menggunakan model dan media seadanya karena kurangnya pemahaman dalam menggunakan komputer atau laptop dalam membantu pembelajaran dikelas. Melihat permasalahan tersebut salah satu alternatif yang dapat dilakukan guru adalah guru mampu mendesain pembelajaran dengan baik, membuat suasana lebih menyenangkan dan mampu memilih model yang sesuai dengan materi dalam pembelajaran IPA yang akan diajarkan. Sehingga siswa mampu mendapatkan nilai atau hasil belajar yang baik dan memuaskan. Seperti yang dikemukakan (Syamsidah, 2017: 1), model merupakan cara menyampaikan atau mentransfer ilmu yang tepat sesuai dengan anak sehingga menghasilkan pemahaman yang maksimal bagi anak yang memperoleh nilai rendah.

Menurut (Suprijono, 2016, p. 51) model pembelajaran adalah suatu perencanaan atau suatu pola pembelajaran yang digunakan sebagai pedoman untuk merencanakan pembelajaran di kelas. Salah satu model pembelajaran yang dapat digunakan untuk mengatasi masalah tersebut adalah dengan menerapkan model pembelajaran kooperatif tipe snowball throwing. Menurut (Istarani, 2014) Snowball Throwing merupakan salah satu model pembelajaran kooperatif. Snowball artinya bola salju sedangkan Throwing artinya melempar. Kegiatan melempar bola pertanyaan ini akan membuat kelompok menjadi semangat dan aktif, karena kegiatan tersebut siswa tidak hanya berfikir, menulis, bertanya atau berbicara. 
219 Pengaruh Model Pembelajaran Kooperatif Tipe Snowball Throwing Berbantuan Media Video Terhadap Hasil Belajar Kognitif Siswa Sekolah Dasar - Islamiati Safitri,Karimah, Emi Sulistri, Dina Anika Marhayani

DOI: https://doi.org/10.31004/edukatif.v4i1.1667

Menurut (Aqib, 2013) Model pembelajaran kooperatif tipe snowball throwing merupakan model pembelajaran yang mengarahkan siswa aktif serta mengalami rasa senang di dalam proses pembelajaran di kelas. Model ini mengarah pada karakteristik siswa usia sekolah dasar, karena berbentuk sebuah permainan. Model pembelajaran kooperatif tipe snowball throwing merupakan salah satu model dalam pembelajaran kooperatif dimana cara pembelajarannya dilakukan secara berkelompok yang kemudian siswa membuat soal pada kertas lembar kerja yang kemudian diremas-remas sampai membentuk bola salju kemudian dilemparkan pada siswa atau kelompok lain untuk dijawab secara langsung. Pemilihan model kooperatif tipe Snowball Throwing dalam penelitian ini, dikarenakan model pembelajaran tersebut memiliki beberapa kelebihan. Sebagaimana (Aris, 2014) menjelaskan bahwa model kooperatif tipe Snowball Throwing ada beberapa kelebihan antara lain: 1) Suasana pembelajaran jadi menyenangkan karena siswa seperti bermain dengan melempar bola kertas kepada siswa lain; 2) Siswa mendapat kesempatan untuk mengembangkan kemampuan berpikir karena diberi kesempatan untuk membuat soal dan diberikan pada siswa lain; 3) Membuat siswa siap dengan berbagai kemungkinan karena siswa tidak tahu soal yang dibuat temannya seperti apa; 4) Siswa terlibat aktif dalam pembelajaran; 5) Pendidik tidak terlalu repot membuat media karena siswa terjun langsung dalam praktik; 6) Pembelajaran menjadi lebih efektif; 7) Ketiga aspek kognitif, afektif, dan psikomotorik dapat tercapai.

Penerapan model pembelajaran Snowball Throwing, juga akan dibantu dengan menggunakan media video pembelajaran agar memotivasi siswa dalam kegiatan belajar. Media pembelajaran juga dapat membantu siswa meningkatkan pemahaman, menyajikan data dengan menarik dan terpecaya, memudahkan menafsirkan dan mendapatkan informasi. Tujuan pemanfaatan media secara umum adalah untuk memfasilitasi berlangsungnya proses belajar dalam diri siswa. Berbagai macam media dapat digunakan untuk membantu siswa dalam mencapai tujuan pembelajaran atau kompetensi yang diinginkan.

Menurut (Latuheru, 1988, p. 14) media pembelajaran adalah semua alat (bantu) atau benda yang digunakan untuk kegiatan belajar mengajar, dengan maksud menyampaikan pesan (informasi) pembelajaran dari sumber (guru maupun sumber lain) kepada penerima (dalam hal ini anak didik atau warga belajar). Media video pembelajaran adalah program video yang dirancang, dikembangkan, digunakan untuk mencapai tujuan pembelajaran. Media video adalah media visual gerak (motion pictures) yang dapat diatur percepatan gerakannya (gerak dipercepat atau diperlambat) (Sujipto, 2011). Hal ini memungkinkan media video efektif bila digunakan untuk membelajarkan pengetahuan yang berhubungan dengan unsur gerak (motion).

Menurut penelitian (Debby Ismi Wulan Putri, I, 2016), terdapat perbedaan yang signifikan antara siswa kelas V yang dibelajarkan dengan model pembelajaran kooperatif tipe snowball throwing berbantuan media power point dan siswa kelas $\mathrm{V}$ yang dibelajarkan dengan pembelajaran konvensional. Penelitian yang relevan juga dilakukan oleh (Wijayanthi, 2014), hasil penelitian menemukan bahwa penerapan model snowball throwing dapat meningkatkan hasil belajar IPA siswa kelas V SD Negeri 4 Suwug. Dapat disimpulkan bahwa model pembelajaran Snowball throwing dalam pembelajaran IPA dapat meningkatkan hasil belajar siswa yang pertama masih tergolong rendah menjadi meningkat.

Berdasarkan latar belakang diatas rumusan masalah dalam penelitian ini yaitu (1) Apakah terdapat pengaruh model pembelajaran kooperatif tipe snowball throwing berbantuan media video terhadap hasil belajar kognitif siswa kelas IV SDN 7 Singkawang? (2) Seberapa besar pengaruh model pembelajaran kooperatif tipe Snowball Throwing berbantuan media video terhadap hasil belajar kognitif siswa kelas IV SDN 7 Singkawang? (3) Bagaimana respon belajar siswa terhadap model pembelajaran Kooperatif Tipe Snowball Throwing berbantuan media video pada pembelajaran IPA di kelas IV SDN 7 Singkawang? 
220 Pengaruh Model Pembelajaran Kooperatif Tipe Snowball Throwing Berbantuan Media Video Terhadap Hasil Belajar Kognitif Siswa Sekolah Dasar - Islamiati Safitri,Karimah, Emi Sulistri, Dina Anika Marhayani

DOI: https://doi.org/10.31004/edukatif.v4i1.1667

\section{METODE PENELITIAN}

Metode penelitian yang digunakan adalah penelitian kuantitatif. Jenis penelitian yang digunakan adalah eksperimen semu (quasi experiment design). Model ini digunakan untuk menguji hipotesis yang behubungan sebab akibat melalui perlakuan dan menguji perubahan yang diakibatkan oleh perlakuan tersebut. Tujuan penelitian ini adalah untuk menganalisis pengaruh model pembelajaran kooperatif tipe snowball throwing berbantuan media video terhadap hasil belajar ranah kognitif siswa dalam pelajaran IPA di kelas IV SDN 07 Singkawang.

Desain penelitian yang digunakan dalam penelitian ini adalah Nonequivalent Control Group Design. Pada penelitian desain ini terdapat dua kelas yaitu kelas eksperimen dan kelas kontrol. Pada kelas eksperimen diberikan perlakuan menggunakan model pembelajaran kooperatif tipe Snowball Throwing dengan berbantuan media video dan pada kelas kontrol model pembelajaran konvensional. Sebelum diberikan perlakuan pada kedua kelas akan dibandingkan hasil belajarnya terlebih dahulu dengan memberikan pretest untuk mengetahui keadaan awal, adakah perbedaan pada kedua kelas tersebut. Selanjutnya, setelah diberikan perlakuan diberikan postest untuk melihat hasil perbedaan setelah diberikan perlakuan. Populasi menurut (Sugiyono, 2013, p. 117) adalah wilayah generalisasi yang terdiri atas objek/subjek yang mempunyai kualitas dan karakteristik tertentu yang ditetapkan oleh peneliti. Populasi dalam penelitian ini adalah seluruh siswa kelas IV di SDN 7 Singkawang yang berjumlah 54 siswa. Sampel adalah sebagian atau wakil dari populasi yang diteliti.. Sampel dalam penelitian ini yaitu kelas IV A yang berjumlah 27 siswa.

Teknik pengumpulan data yang digunakan dalam penelitian ini adalah teknik tes dan non tes. Tes yang dilakukan menggunakan instrument berupa soal pilihan ganda mengenai materi bunyi. Tes ini diberikan kepada dua kelas penelitian yaitu pada kelas kontrol dan kelas eksperimen yang mana akan dilakukan prettest dan posttest. Tes dilakukan untuk mengetahui hasil belajar ranah kognitif IPA. Teknik non tes yang digunakan dalam penelitian ini dengan memberikan lembar angket respon siswa yang betujuan untuk mengetahui respon siswa terhadap model pembelajaran kooperatif tipe snowball throwing berbantuan media video. Setelah peneliti mengumpulkan data melalui tes langkah selanjutnya adalah menganalisis data. Kegiatan analisis data berdasarkan variabel dari seluruh responden, menstabulasi data berdasarkan variabel dari seluruh responden, menyajikan data tiap variabel yang diteliti, melakukan perhitungan untuk menguji hipotesis yang telah diajukan. Teknik analisis data yang digunakan dalam penelitian ini adalah analisis kuantitatif dan statistika. Pada penelitian ini akan diperoleh data kuantitatif sehingga untuk menganalisis data didapatkan dari pemberian tes hasil belajar dan penyebaran angket akan dilakukan teknik statistik.

\section{HASIL DAN PEMBAHASAN PENELITIAN}

\section{1. .Deskripsi Hasil Belajar}

\section{a. Deskripsi Hasil Belajar Siswa Kelas Kontrol dan Eksperimen}

Berdasarkan hasil perhitungan data pretest dan data posttest yang diperoleh di kelas kontrol maka didapat nilai rata-rata, standar deviasi, varians, skor tertinggi dan skor terendah. Untuk selengkapnya dapat disajikan pada Tabel 1 sebagai berikut:

Tabel 1 Rekapitulasi Data Hasil Belajar

\begin{tabular}{lll}
\hline Statistika & Eksperimen & Kontrol \\
\hline Rata-rata & 70,03 & 44,64 \\
\hline Standar Deviasi & 24,51 & 18,37 \\
\hline Nilai Tertinggi & 90 & 85 \\
\hline
\end{tabular}


221 Pengaruh Model Pembelajaran Kooperatif Tipe Snowball Throwing Berbantuan Media Video Terhadap Hasil Belajar Kognitif Siswa Sekolah Dasar - Islamiati Safitri,Karimah, Emi Sulistri, Dina Anika Marhayani

DOI: https://doi.org/10.31004/edukatif.v4i1.1667

\begin{tabular}{lll}
\hline Nilai Terendah & 15 & 20 \\
\hline Jumlah Siswa & 27 & 27 \\
\hline
\end{tabular}

Rekapitulasi nilai siswa kelas kontrol dan eksperimen disajikan dalam bentuk diagram batang dapat dilihat pada gambar 1 sebagai berikut:

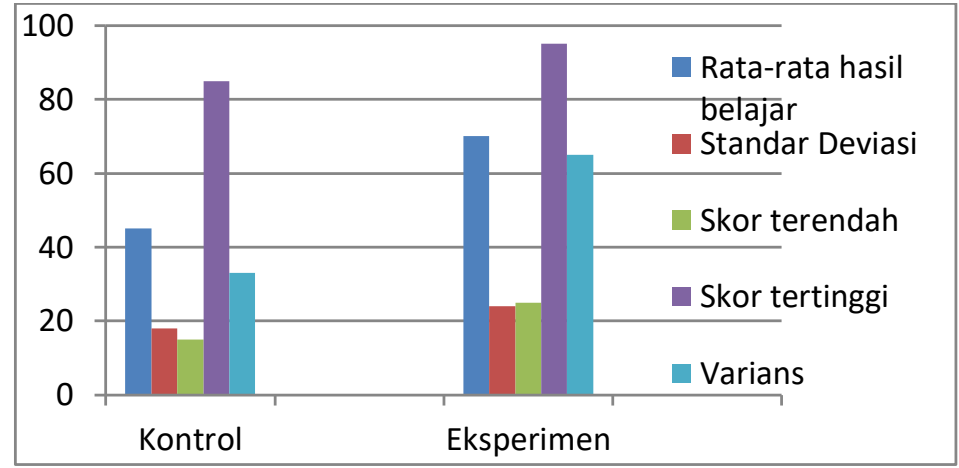

\section{Gambar 1. Diagram Batang Nilai Pretest dan Posttest Siswa Kelas Kontrol}

Berdasarkan Tabel 1 dapat diketahui untuk hasil pretest siswa di kelas kontrol diperoleh nilai rata-rata 44,64, standar deviasi sebesar 18,37, dengan skor tertinggi 85 dan skor terendah 15. Kemudian untuk posttest diperoleh nilai rata-rata 70,03, standar deviasi sebesar 24,51, dengan skor tertinggi 90 dan skor terendah 20.

\section{b. Uji rata-rata kelas eksperimen dan kelas control}

Untuk mengetahui perbedaan hasil belajar siswa antara kelas ekperimen dan control di kelas IV SDN 7 Singkawang menggunakan uji t dua sampel. Namun sebelumnya akan dilakukan uji normalitas dan homogenitas terlebih dahulu.

\section{c. Uji Normalitas}

Uji normalitas dilakukan untuk mengetahui apakah data posttest yang telah dikumpulkan berasal dari populasi yang berdistribusi normal atau tidak sehingga langkah selanjutnya tidak menyimpang dari kebenaran dan dapat di pertanggung jawabkan. Hasil uji normalitas data posttest hasil belajar siswa kelas eksperimen yaitu $\mathrm{X}^{2}{ }_{\text {hitung }} 7.155$ dan kelas kontrol dapat yaitu $\mathrm{X}_{\text {hitung }}$-8.580. Dapat disimpulkan hasil uji normalitas data kelas eksperimen dan kontrol berdistribusi normal.

\section{d. Uji Homogenitas data menggunakan rumus $f$}

Setelah data skor post-test kelas eksperimen dan kelas kontrol dihitung dan didapatkan data tersebut berdistribusi normal, selanjutnya akan melakukan uji homogenitas data menggunakan rumus f. Diketahui varians kelas eksperimen yaitu 551.99 dan menjadi varians terbesar, sedangkan varians kelas kontrol adalah 337.67 dan menjadi varians terkecil sehingga $\mathrm{f}_{\text {hitung }}$ adalah 0,611. Dari $\mathrm{f}_{\text {tabel }}$ dengan ${ }^{\alpha}=7 \%$ dan dk pembilang 27 dan dk penyebut 27 diperoleh $\mathrm{f}_{\text {tabel }}=1.92$. Karena $\mathrm{f}_{\text {hitung }}<\mathrm{f}_{\text {tabel }}$ yaitu $0.611<1.92$ maka kelas eksperimen dan kelas kontrol mempunyai varians yang sama atau homogen. Karena data nilai pada kelas eksperimen dan kontrol berdistribusi normal dan homogen, maka selanjutnya dilakukan uji t dua sampel untuk mengetahui apakah terdapat pengaruh hasil belajar siswa antara kelas yang diberikan model pembelajaran Kooperatif tipe snowball throwing berbantuan media video dengan kelas yang diberikan pembelajaran langsung di kelas IV SDN 7 Singkawang. 
222 Pengaruh Model Pembelajaran Kooperatif Tipe Snowball Throwing Berbantuan Media Video Terhadap Hasil Belajar Kognitif Siswa Sekolah Dasar - Islamiati Safitri,Karimah, Emi Sulistri, Dina Anika Marhayani

DOI: https://doi.org/10.31004/edukatif.v4i1.1667

\section{e. Uji perbedaan kelas eksperimen dan kontrol menggunakan uji t dua sampel}

Berdasarkan uji normalitas dan homogenitas diperoleh bahwa data post-test kelas eksperimen maupun kelas kontrol berdistribusi normal dan mempunyai varians yang sama atau homogen. Maka untuk menguji kesamaan rata-rata kedua kelas menggunakan uji $t$ dua sampel. Berikut hasil peerhitungan uji t dua sampel:

Tabel 2 Hasil Perhitungan Uji $t$ dua sampel

\begin{tabular}{llllll}
\hline Kelompok & $\mathrm{dk}$ & $\alpha$ & $\mathrm{t}_{\text {hitung }}$ & $\mathrm{t}_{\text {tabel }}$ & Keputusan \\
\hline $\begin{array}{l}\text { Eksperimen } \\
\text { dan kontrol }\end{array}$ & 54 & $7 \%$ & 2.131 & 2.00665 & Ha diterima \\
\hline
\end{tabular}

Berdasarkan tabel 2 diatas, diketahui $t_{\text {hitung }}=2.131$ dan $t_{\text {tabel }}=2.00665$ diperoleh $t_{\text {hitung }}>t_{\text {tabel }}$ yaitu 2.131 > 2.00665 maka Ha diterima dan Ho ditolak. Sehingga dapat disimpulkan bahwa terdapat perbedaan hasil belajar siswa antara kelas yang diberikan model pembelajaran kooperatif tipe snowball throwing berbantuan media video dengan pembelajaran langsung di kelas IV SDN 7 Singkawang. Besar pengaruh penggunaan model pembelajaran Kooperatif tipe snowball throwing berbantuan media video terhadap hasil belajar, maka digunakan rumus Effect size (Es).

2. Uji Besarnya Pengaruh Penggunaan Model Pembelajaran Kooperatif Tipe Snowball Throwing Berbantuan Media Video Terhadap Hasil Belajar Kognitif Siswa Kelas IV SDN 7 Singkawang.

Untuk mengetahui seberapa besar pengaruh model pembelajaran Kooperatif tipe Snowball throwing berbantuan media video terhadap hasil belajar kognitif siswa, maka menggunakan rumus Effect size (Es). Adapun hasil dari perhitungan Effect size (Es) sebagai berikut:

Tabel 3 Hasil Uji Effect size (Es)

\begin{tabular}{lll}
\hline \multirow{2}{*}{ Perhitungan } & Kelas & \\
\cline { 2 - 3 } & Eksperimen & Kontrol \\
\hline Rata-rata $(\mathrm{X})$ & 70,03 & 44,64 \\
\hline Standar Deviasi Kelas Kontrol $\left(\mathrm{S}_{\mathrm{C}}\right)$ & 24,51 & 18.37 \\
\hline Effect Size (Es) & 1,38 & \\
\hline Kriteria & Tinggi & \\
\hline
\end{tabular}

Dari Tabel 3 dapat dilihat bahwa $E s=1,38$ dan kriterianya tinggi karena 1,38 berada pada $E S>0,8$ maka Ha diterima Ho ditolak. Dapat disimpulkan penggunaan model pembelajaran kooperatif tipe snowball throwing berbantuan media video berpengaruh tinggi terhadap hasil belajar kognitif siswa dikelas IV SDN 7 Singkawang.

\section{Hasil Angket Respon Siswa}

Hasil data respon siswa terhadap model pembelajaran kooperatif tipe snowball throwing berbantuan media video diperoleh melalui lembar angket respon siswa yang disebarkan kepada seluruh siswa kelas eksperimen yang berjumlah 27 siswa. Data disajikan berupa tanggapan terhadap pernyataan-pernyataan yang terdapat pada angket respon siswa. Adapun hasil analisis angket respon siswa yang disajikan pada Tabel 4.7 sebagai berikut:

Tabel 4 Hasil analisis angket respon siswa

\begin{tabular}{lll}
\hline Indikator & Persentase (\%) & Kategori Respon \\
\hline Mendekati & $70 \%$ & Baik \\
\hline Menyukai & $75 \%$ & Baik \\
\hline
\end{tabular}


223 Pengaruh Model Pembelajaran Kooperatif Tipe Snowball Throwing Berbantuan Media Video Terhadap Hasil Belajar Kognitif Siswa Sekolah Dasar - Islamiati Safitri,Karimah, Emi Sulistri, Dina Anika Marhayani

DOI: https://doi.org/10.31004/edukatif.v4i1.1667

\begin{tabular}{lll}
\hline Menyenangi & $70 \%$ & Baik \\
\hline Mengharapkan suatu objek & $65 \%$ & Baik \\
\hline Rata-rata respon siswa & $70 \%$ & Baik \\
\hline
\end{tabular}

Berdasarkan Tabel 4 hasil analisis angket respon siswa dapat dideskripsikan pada kriteria tanggapan yang indikator mendekati masuk golongan interval $70 \%$ dengan kriteria baik, pada keriteria reaksi yang indikator menyukai masuk golongan interval $75 \%$ dengan kriteria baik, pada indikator menyenangi masuk dalam golongan interval 70\% dengan kriteria baik dan pada indikator mengharapkan suatu objek masuk dalam golongan interval 65\% dengan kriteria baik, karena banyak yang masuk pada kriteria baik dengan rata-rata keseluruhan respon siswa terdapat 70\% dengan kriteria baik. Dengan hasil ini, dapat dikatakan bahwa siswa mempunyai respon positif terhadap pembelajaran IPA dengan menggunakan model pembelajaran kooperatif tipe snowball throwing berbantuan media video.

\section{PEMBAHASAN}

Berdasarkan hasil pengujian hipotesis, maka terlihat bahwa hipotesis yang digunakan pada penelitian ini berhasil mendapat hipotesis alternatif, dan rincian hipotesis sebagai berikut:

\section{Pengaruh Hasil Belajar Kognitif Siswa}

Berdasarkan Dari hasil pengujian hipotesis menunjukkan bahwa pembelajaran IPA dengan menggunakan Model pembelajaran Kooperatif Tipe Snowball throwing berbantuan Media Video Di Kelas IV SDN 7 Singkawang lebih tinggi dari pada sebelum diberikan model pembelajaran kooperatif tipe snowball throwing berbantuan media video. Hal ini terbukti pada pengujian hipotesis yang menggunakan uji $\mathrm{t}$ test, dengan membandingkan nilai $t$ hitung dengan $t$ tabel kemudian diperoleh nilai $-\mathrm{t}$ tabel $>$-thitung 2.131033852 > - 2.00665 berarti Ho ditolak dan Ha diterima, dapat disimpulkan bahwa terdapat pengaruh model pembelajaran kooperatif tipe snowball throwing berbantuan media video terhadap hasil belajar kognitif siswa.

Karena sebelum diterapkan model pembelajaran kooperatif tipe Snowball Throwing siswa kurang memperhatikan penjelasan guru saat menjelaskan. Siswa kurang aktif pada saat proses pembelajaran berlangsung. Selain itu, guru tidak melibatkan siswa pada saat proes pembelajaran berlangsung dan kurang memperhatikan siswa bosan atau tidak saat belajar, sehingga berdampak nilai hasil belajar siswa masih tergolong rendah. sedangkan setelah penerapan model pembelajaran kooperatif tipe Snowball Throwing pada kelas eksperimen, proses pembelajaran lebih aktif dan menumbuhkan semangat siswa untuk belajar, karena guru melibatkan siswa dalam pembelajaran langsung, sehingga proses belajar siswa menjadi lebih aktif.

Hal ini dikarenakan model pembelajaran kooperatif Snowball Throwing ini memiliki beberapa kelebihan yaitu: 1) Meningkatkan jiwa kepemimpinan siswa sebab ada ketua dalam kelompok yang diberi tugas untuk menjelaskan materi kepada teman-temannya. 2) Melatih siswa untuk belajar mandiri karena masing-masing siswa diberikan tugas untuk membuat satu pertanyaan lalu pertanyaan itu akan dilemparkan kepada teman-temannya dan dijawab oleh siswa yang mendapatkan pertanyaan. 3) Menumbuhkan kreativitas dan pola pikir saat belajar siswa karena membuat pertanyaan ataupun menjawab soal dari temannya. 4) Suasana pembelajaran lebih menyenangkan karena siswa seperti bermain dengan melemparkan bola kertas yang berisi pertanyaan untuk siswa yang mendapatkan bola kertas tersebut. 5) Siswa terlibat aktif dalam pembelajaran. Menurut (Jumanta, 2014, p. 161) juga menjelaskan mengenai kelebihan dari model pembelajaran Snowball Throwing bahwa dengan menerapkan model pembelajaran Snowball Throwing dapat membuat suasana menjadi lebih menyenangkan, siswa juga diberikan kesempatan untuk mengembangkan kemampuan berfikir, dan pembelajaran menjadi lebih efektif. 
224 Pengaruh Model Pembelajaran Kooperatif Tipe Snowball Throwing Berbantuan Media Video Terhadap Hasil Belajar Kognitif Siswa Sekolah Dasar - Islamiati Safitri,Karimah, Emi Sulistri, Dina Anika Marhayani

DOI: https://doi.org/10.31004/edukatif.v4i1.1667

Sejalan dengan penelitian yang dilakukan (Sri Putri, 2017), menyatakan bahwa hasil belajar IPA dengan menggunakan model pembelajaran Snowball throwing siswa mendapat perlakuan lebih baik dari pada pembelajaran konvensional. Sehingga dapat disimpulkan bahwa terdapat pengaruh hasil belajar kognitif siswa dengan menerapkan model pembelajaran kooperatif Tipe snowball throwing berbantuan media video.

\section{Besar pengaruh model pembelajaran Kooperatif tipe Snowball Throwing berbantuan media video terhadap hasil belajar kognitif siswa.}

Untuk mengetahui seberapa besar pengaruh yang ditimbulkan, maka langkah selanjutnya dilakukan uji Effect size. Dari hasil perhitungan Effect size tersebut menunjukkan bahwa pembelajaran dengan menggunakan model pembelajaran Kooperatif tipe snowball throwing berbantuan media video memberikan pengaruh yang tinggi terhadap hasil belajar kognitif siswa pada materi Bunyi. Model pembelajaran kooperatif tipe Snowball Throwing dapat menigkatkan aktivitas dan kreatifitas siswa, melatih siswa belajar mandiri dalam pengetahuan berdasarkan diskusi, mengembangkan kemampuan berpikir siswa dalam mendiskusikan dan meyelesaikan tugas belajar, mengembangkan kemampuan mengemukakan pendapat, meningkatkan kemampuan menjelaskan kembali materi yang diperoleh berdasarkan diskusi, dan meningkatkan hasil belajar siswa (Rosidah, 2017). Model pembalajaran Kooperatif tipe snowball throwing adalah suatu model pembelajaran dimana siswa dapat membangkitkan keberanian siswa dalam mengemukakan sebuah pendapatnya dan mempermudah siswa dalam mempelajari sebuah materi. Salah satu kelebihan model pembelajaran menurut (Aris, 2014) adalah membuat siswa lebih aktif dan membuat siswa lebih cepat mengerti dalam hal pembelajaran yang disampaikan.

Besarnya pengaruh yang diperoleh dikarenakan dalam proses pembelajaran yang terjadi dikelas eksperimen menggunakan model pembelajaran Kooperatif tipe Snowball Throwing dengan bantuan media video dengan tahapan yaitu guru menjelaskan materi dan model pembelajaran yang akan di terapkan. Guru membagi siswa ke dalam kelompok yang terdiri dari 4-5 siswa tiap kelompoknya. Kemudian guru menampilkan materi melalui tayangan video pembelajaran dan siswa diminta untuk mengamati. Masingmasing kelompok diberikan satu lembar kerja untuk menuliskan pertanyaan dari materi yang telah ditayangkan di video pembelajaran. Kemudian kertas tersebut dibuat seperti bola dan dilempar dari satu kelompok ke kelompok yang lain sesuai dengan perintah guru. Setelah siswa mendapat bola atau satu pertanyaan diberikan kesempatan kepada kelompok lain untuk menjawab pertanyaan tertulis dalam kertas berbentuk bola tersebut. Guru memberikan penguatan dan siswa mengerjakan evaluasi. Keadaan siswa dalam proses pembelajaran terlihat lebih bersemangat dan menyenangkan, sehingga siswa memiliki ketertarikan dan menjadi aktif. Model pembelajaran "Snowball Throwing merupakan pembelajaran yang diadopsi pertama kali dari game fisik dimana segumpalan salju yang dilempar dengan maksud memukul orang lain" (Huda, 2013, p. 226). Model pembelajaran kooperatif tipe Snowball Throwing juga memberikan pengalaman kepada siswa untuk mengembangkan keterampilan menyimpulkan isi berita atau informasi yang mereka peroleh dalam konteks nyata dan situasi yang kompleks.

Model pembelajaran Kooperatif tipe snowball throwing adalah suatu tipe model pembelajaran yang menggali potensi kepemimpinan siswa dalam kelompoknya. Hal ini sejalan dengan penelitian yang dilakukan oleh (Kusumawati, 2017) yang menyimpulkan bahwa hasil belajar siswa baik secara keseluruhan maupun siswa yang berkemampuan diawal tinggi, sedang dan rendah yang belajar dengan model pembelajaran Kooperatif tipe Snowball Throwing berbantuan media video, lebih baik dari pada hasil belajar siswa baik secara keseluruhan maupun siswa berkemampuan awal tinggi, sedang dan rendah yang belajar dengan pembelajaran konvensional. Temuan dalam penelitian ini sejalan dengan hasil penelitian yang ditemukan oleh Hendy (2018), bahwa penerapan model pembelajaran Snowball Throwing dapat meningkatkan hasil belajar siswa karena model ini sangat membantu siswa dalam melakukan diskusi dan kerjasama antar teman. Hal ini 
225 Pengaruh Model Pembelajaran Kooperatif Tipe Snowball Throwing Berbantuan Media Video Terhadap Hasil Belajar Kognitif Siswa Sekolah Dasar - Islamiati Safitri,Karimah, Emi Sulistri, Dina Anika Marhayani

DOI: https://doi.org/10.31004/edukatif.v4i1.1667

berarti model pembelajaran Kooperatif tipe Snowball Throwing berbantuan media video berpengaruh baik terhadap pemahaman konsep.

\section{Respon Belajar Siswa}

Pada akhir pembelajaran dengan model pembelajaran kooperatif tipe snowball throwing berbantuan media video, siswa di berikan lembar angket respon belajar siswa untuk mengetahui respon belajar siswa dalam mengikuti proses pembelajaran dengan model kooperatif tipe snowball throwing berbantuan media video. Dalam penelitian ini angket respon belajar siswa digunakan dengan skala gutman. Kemudian siswa hanya dapat memilih satu pilihan dari kolom YA dan TIDAK.

Hal ini sesuai dengan indikator yang pertama mendekati, yaitu dengan menggunakan model pembelajaran kooperatif tipe snowball throwing berbantuan media video membuat siswa termotivasi dalam belajar. Indikator yang kedua menyukai yaitu model pembelajaran kooperatif tipe snowball throwing berbantuan media video menarik untuk diterapkan dalam belajar. Indikator yang ketiga menyenangi yaitu model pembelajaran kooperatif tipe snowball throwing berbantuan media video menyenangkan dan membuat siswa menjadi semangat dalam belajar. Indikator yang keempat mengharapkan suatu objek yaitu dengan diterapkannya model pembelajaran kooperatif tipe snowball throwing berbantuan media video membuat siswa dapat mengemukakan pendapat dalam proses pembelajaran.

Dari hasil analisis data mengenai respon belajar siswa diperoleh rata-rata angket respon belajar siswa secara keseluruhan sebesar 70\%. Maka dapat disimpulkan bahwa respon belajar siswa dinyatakan baik terhadap model pembalajaran kooperatif tipe snowball throwing berbantuan media video terhadap hasil belajar kognitif siswa. Sejalan dengan penelitian (Hujaemah. E. Saefurrohman. A., 2019) dari hasil kesimpulan penelitiannya menyatakan bahwa siswa yang menggunakan model pembelajaran kooperatif tipe snowball throwing lebih baik.

\section{KESIMPULAN}

Berdasarkan kedua hal tersebut dikembangkan pokok-pokok pikiran baru yang merupakan esensi dari temuan penelitian. Berdasarkan hasil pengelolaan data hasil penelitian dan pembahasan secara umum dapat disimpulkan bahwa model pembelajaran kooperatif tipe snowball throwing berbantuan media video dapat memberikan pengaruh yang tinggi terhadap hasil belajar kognitif IPA siswa dikelas IV SDN 7 Singkawang. Disimpulkan beberapa hal sebagai berikut 1) Terdapat pengaruh model pembelajaran koooperatif tipe snowball throwing berbantuan media video terhadap hasil belajar kognitif siswa dengan yakni hasil thitung > $\mathrm{t}$ tabel= $2.131033852>2.00665$ maka Ha diterima dan Ho ditolak. Hal ini dikarenakan model pembelajaran kooperatif tipe snowball throwing berbantuan media video membuat siswa aktif dalam proses pembelajaran yang disampaikan. 2) Pengaruh model pembelajaran Kooperatif tipe snowball throwing berbantuan media video terhadap hasil belajar kognitif siswa, hasil analisis yang diperoleh yaitu kategori tinggi dengan skor 1,37 Hal ini menunjukkan bahwa model Pembelajaran Kooperatif Tipe Snowball Throwing berbantuan media video memberikan pengaruh besar terhadap hasil belajar kognitif siswa. 3) Berdasarkan hasil perhitungan persentase respon belajar siswa termasuk dalam kategori baik, dengan hasil persentase $70 \%$. Hal ini menunjukkan respon siswa yang baik terhadap pembelajaran menggunakan model pembelajaran kooperatif tipe snowball throwing berbantuan media video terhadap hasil belajar kognitif siswa. 
226 Pengaruh Model Pembelajaran Kooperatif Tipe Snowball Throwing Berbantuan Media Video Terhadap Hasil Belajar Kognitif Siswa Sekolah Dasar - Islamiati Safitri,Karimah, Emi Sulistri, Dina Anika Marhayani

DOI: https://doi.org/10.31004/edukatif.v4i1.1667

\section{UCAPAN TERIMA KASIH}

Ucapan terima kasih disampaikan kepada Direktorat Jenderal Pendidikan Tinggi, Riset, dan Teknologi, Kementrian Pendudukan Kebudayaan, Riset, dan Teknologi untuk mendukung pendanaan melalui Program Talenta Inovasi Indonesia Ta 2021 Gelombang 1.

\section{DAFTAR PUSTAKA}

Agustiana, I. G. A. (2009). Konsep Dasar Ipa Aspek Biologi. Penerbit Ombak.

Aqib, Z. (2013). Model-Model Dan Strategi Pembelajaran Konstektual Inovatif. Yrama Widya.

Aris, S. (2014). Model Pembelajaran Inovatif Dalam Kurikulum 2013. Ar-Ruzz Media.

Debby Ismi Wulan Putri, I, S. (2016). Penerapan Model Snowball Throwing Terhadap Aktivitas Dan Kognitif Siswa. Pendidikan Dasar Perkhansa, 2(2).

Huda, M. (2013). Model-Model Pengajaran Dan Pembelajaran. Pustaka Pelajar.

Hujaemah. E. Saefurrohman. A., \& J. (2019). Pengaruh Penerapan Model Snowball Throwing Terhadap Hasil Belajar Ipa Di Sekolah Dasar. Madrasah Ibtidaiyah, 5(1).

Iskandar, S. M. (1997). Pendidikan Ilmu Pengetahuan Alam. Dikti.

Istarani. (2014). 58 Model Pembelajaran Inovatif. Media Persada.

Jumanta, H. (2014). Model Dan Metode Pembelajaran Kreatif Dan Berkarakter. Ghalia Indonesia.

Kusumawati, N. (2017). Pengaruh Model Pembelajaran Kooperatif Dengan Snowball Throwing Terhadap Hasil Belajar Ipa Siswa. Kependidikan Dasar Islam Berbasis Sains, 2(1).

Latuheru, J. D. (1988). Media Pembelajaran Dalam Proses Belajar-Mengajar Masa Kini. Departemen Pendidikan Dan Kebudayaan.

Mariana, A. I. M. Dan W. P. (2009). Hakikat Ipa Dan Pendidikan Ipa. Pppptk Ipa.

Rosidah, A. (2017). Penerapan Model Pembelajaran Kooperatif Snowball Throwing Untuk Meningkatkan Hasil Belajar Pada Pembelajaran Ips. Cakrawala Pendas, 3(2).

Sari, D. K. (2012). Buku Ajar Pembelajaran Ipa. Upt Undip.

Sri Putri, N. . (2017). Pengaruh Model Pembelajaran Kooperatif Tipe Snowball Throwing Berbantuan Media Power Point Terhadap Hasil Belajar Ipa. Pgsd Universitas Pendidikan Ganesha, 5(2).

Sugiyono. (2013). Metode Penelitian Kuantitatif, Kualitatif Dan R\&D. Alfabeta.Cv.

Sujipto, K. D. (2011). Media Pembelajaran Manual Dan Digital. Ghalia Indonesia.

Suprijono, A. (2016). Cooperative Learning Teori Dan Aplikasi Paikem. Pustaka Pelajar.

Syamsidah. (2017). 100 Metode Pembelajaran. Deepublish.

Wijayanthi, M. R. (2014). Penerapan Metode Pembelajaran Snowball Throwing Untuk Meningkatkan Hasil Belajar Ipa Siswa Kelas V Sd. Mimbar Pgsd, 2(1) 